\title{
Vocational Education at Special School in North Sumatra
}

\author{
Munawir Pasaribu ${ }^{1}$, Rizka Harfiani 2 \\ DOI: 10.35445/alishlah.v13i2.641
}

Article Info

Keywords:

Education;

Vocational;

Special

Children;

Special Schools

Kata kunci:

Pendidikan;

Vokasional;

Anak Berkebutuhan

Khusus;

Sekolah Luar Biasa

\begin{abstract}
Vocational education is the proper treatment of work skills or life skills education, especially for students with special needs. This study aims to analyze the implementation of vocational education at A/B/C Melati 'Aisyiyah special school located in Tembung, North Sumatra Province, Indonesia. This study uses a qualitative approach, with field research type. The data collection is through observation, interview, and documentation, then analyzed with interactive analysis models, following the data validity test using triangulation methods. This study discovers that analyzing the vocational education implementation for special students at the high school level, namely from aspects: a) teacher potential, b) student potential, c) supporting infrastructure, d) vocational learning system and policy to grant students to work according to their ability, as one of the efforts to realize the school vision and mission. The implication of this study is to provide an overview of vocational education implementation for special students to have independence and responsibility in living their lives.
\end{abstract}

\begin{abstract}
Abstrak
Pendidikan vokasional adalah pendidikan keterampilan kerja atau kecakapan hidup yang tepat diberikan bagi siswa, terutama bagi siswa berkebutuhan khusus. Penelitian ini bertujuan untuk menganalisis pelaksanaan pendidikan vokasional di Sekolah Luar Biasa A/B/C Melati 'Aisyiyah yang berlokasi di Tembung, Provinsi Sumatera Utara, Indonesia. Penelitian ini menggunakan pendekatan kualitatif, dengan jenis field research. Teknik pengumpulan data melalui observasi, wawancara, dan dokumentasi, yang kemudian dianalisis dengan model analisis interaktif, serta uji keabsahan data menggunakan metode triangulasi. Temuan hasil penelitian, menganalisis pelaksanaan pendidikan vokasional bagi siswa berkebutuhan khusus setingkat sekolah menengah atas, yaitu dari aspek: a) potensi guru, b) potensi siswa, c) dukungan sarana prasarana, d) sistem pembelajaran vokasional dan kebijakan memberikan izin praktik bekerja bagi para siswa sesuai kemampuannya, sebagai salah satu upaya mewujudkan visi dan misi sekolah. Implikasi dari hasil penelitian ini adalah memberikan gambaran dalam pelaksanaan pendidikan vokasional bagi siswa berkebutuhan khusus agar memiliki kemandirian dan tanggung jawab dalam menjalani kehidupannya.
\end{abstract}

\footnotetext{
${ }^{1}$ University of Muhammadiyah Sumatera Utara, Medan, Indonesia Email: munawirpasaribu@umsu.ac.id 2 University of Muhammadiyah Sumatera Utara, Medan, Indonesia Email: rizkaharfiani@umsu.ac.id
} 


\section{INTRODUCTION}

Education is a means for improving the individuals' quality to be better, in terms of personality, skills, intelligence, and social. Education is comprehensive, including for Special children. Children with special needs experience visual, hearing, intelligence, psychomotor, emotional, and social problems. They require special services in academic and vocational programs. Vocational skills are self-potential and can be found in individuals living decently and dignifiedly in the community (Iswari, 2008).

Vocational education in special schools provides the students with entrepreneurial ability, skills, and careers in specific fields customized with special students' abilities (Dasel \&Marcus, 2019). Vocational education is either way intended to increase self-reliance, especially in conducting economic activities for special students (Wiratman et al., 2018). A study at Styrian LSA Austria states that vocational skills training provided during school years could be satisfied in supporting people with disabilities to obtain employment (Breyer et al., 2020). The advantages of vocational education for exceptional children are the result of the transition from the educational process to independent and worker life, by assignment, access, arrangement, teaching requests, attitudes, and teacher readiness, along with speculation about the school reform impact and government legislation (Evers, 1996).

Education for special children had to observe the characteristics and necessities that support the special children's independence in the future. The curriculum implementation for special children at the high school level should prioritize the vocational skills, with $40 \%$ academic material and 60\% vocational learning (Wijaya, 2018). Vocational education is a specialized education that includes every work level. The lessons are based on theory development and practice intended to help individuals ready to compete in the work world according to their talents, interests, and potentials (Afriliani, 2016). Vocational skills are skills related to a particular field that exists in society (Sani, 2016).

The Special School's main objective with vocational programs is to produce graduates who can enter the work world or the community and are expected to be independent and responsible (Cendaniarum, 2020). The Indonesia Government support to achieve the Special School goal is issuing Law Number 8 of 2016, which states that private companies are obliged to employ $1 \%$ of people with disabilities. This proves that the government provides opportunities in education and employment for people with disabilities (Prihatin et al., 2018). Study shows vocational education importance for special students in Special School to have independence and skills in the world of work (Tomblin \&Haring, 1999).

Some factors influence the vocational learning process quality: teachers, infrastructure, financial, leadership, working climate, students capability, and local support (Ekosiswoyo \&Sutarto, 2015). An example of local potential-based vocational learning is a study in Kalimantan that utilizes jengkol as the main ingredient to make various foods worth selling (Lia et al., 2017). The study result that conducted at 23 schools in Bandung city discovered that the types of vocational skills performed by the schools varied, the most schools conduct craft skills (49\%), culinary (19\%), fashion (12\%), agriculture (7\%), services (5\%), sports (1\%), computer (1\%), art (1\%) and photography (1\%). The vocational type selection is based on the school agreement (13\%), Student condition adjustment independence support of mentally disabled children(26\%), the work environment adjustment or activities in school (22\%) (Ratnengsih, 2017).

Educating special children requires the teacher's competence skills by applying the right strategies and learning methods and the facilities and infrastructure capable of accommodating the learning necessities (Akrim \&Harfiani, 2019). Some learning methods that used in vocational education for exceptional students in a particular school, among others: training methods (Haryeti et al., 2013) and direct learning methods in cooking lessons for deaf students (Ainun \&Martias, 2020), demonstration methods (Amelia \&Armaini, 2020) and project methods in handcraft are 
learning on mental children (Ningtyas, 2020), direct instruction method in hand skills learning for children (Pratama \&Efendi, 2019), the use of video media in vocational learning of culinary for deaf students (Anisa, 2020), explicit instruction method on planting skills for mental children (Safera \&Hasan, 2019), and training methods /Drill on deaf students (Saptaringga, 2014).

Kinds of vocational skills given to students with special needs, among others: in the work, learning handycraft skills to improve entrepreneurship (Faroga et al., 2018), creating tissue box and flannel clothes for deaf children (Pratama \&Efendi, 2019), making leather sandals for mental children (Seprinawati and Jon Efendi, 2019); in culinary skill learning, (Prayogo, 2019), such as making brownies (Ainun \&Martias, 2020), palai rinuak food from rinuak fish (Haryeti et al., 2013), grilled fish for children with hearing problem (Muspita et al., 2018), making salted eggs for children with tunagragita (Riyani et al., 2016), making spring roll skin chips for mental students (Subagja, 2020); in service fields such as , laundry skills for children with mental disorder (Rahmawati, 2019), motorcycle cleaning skills for light mental disorder children (Rizqi, 2020), massage skills in visually impaired children (Yustika, 2020), barber skills for deaf students (Zuliansyah, Muhammad \&Hasan, 2018); in agriculture, such as growing celery for mental children ( Safera \&Hasan, 2019); in areas of expertise, such as automotive skills in students with disabilities (deaf) (Saptaringga, 2014), and many other skills that can be provided for special students who become their provision in entering the world of work in the community.

The work skills of special school graduates are often a problem at the National and International levels. The results showed that 70\% of people with disabilities were employed but did not match the vocational skills they gained in the school. The improvement can ensure the job market that suits the disability type (Yusof et al., 2014). The main obstacles in implementing the vocational program are students with limited abilities; the solution is to repeat the lessons and the school follow-up to help the students get into the world of work (Mufiddah et al., 2019). The obstacles that are often found in the implementation of the vocational skills are the learning aspect (78\%), the aspect of facilities and infrastructure (13\%), the human resources (5\%), and the marketing aspect of product results (4\%) (Ratnengsih, 2017). The education problems for special children can be solved by the consideration and cooperation from various parties and the full support of parents, teachers, schools, communities, and the government (Harfiani \&Akrim, 2020).

The ICF survey results (International Classification of Functioning, Disability, and Health) show that $74.4 \%$ of people with disabilities are unemployed (Marjuki, 2010). The highest percentage of people with disabilities who were unemployed was occupied by mental disorder (Purwanta \&Hulfa, 2018). Another study showed that about $73 \%$ of children with mentals who have graduated from school are unemployed or have not obtained a job (Rusdiansyah \&Sujarwanto, 2013). Therefore vocational education is needed as a provision of skills for students in Special schools.

The description above is the background of this study by raising how the implementation of vocational education conducted by the Special School of A/B/C Melati 'Aisyiyah in North Sumatra. By learning various skills in vocational education, students with special needs are expected to gain perceptual experience, appreciative experience, and creative experience (Jaya et al., 2018).

\section{METHODS}

This qualitative study is field research, where the author directly comes into the field to obtain the required data. The qualitative approach, by conducting research-oriented to natural symptoms. Therefore, it is naturalistic and fundamental or natural and can not be done in the laboratory but must be in the field. The qualitative study processes involve essential efforts, such as questioning, collecting data procedures from participants, analyzing and interpreting the meaning of data (Creswell, 2010).

This study observed the vocational education process conducted at A/B/C Melati'Aisyiyah special school at Masjid street No. 806 Pasar IX Tembung, Bandar Khalifah Village, Percut Sei Tuan subdistrict, Deli Serdang Regency, North Sumatra Province. The study was conducted in the first 
semester of the 2020/2021 academic school year, transitioning from the COVID 19 pandemic to the new normal era. So that when this study takes place the process of academic education is through online and a home visit, while vocational education through offline, by demonstration methods and direct practice by the student, especially for high school students.

Data collection techniques are conducted through:

a) Observation. The qualitative observations that researchers directly go down to the field to observe the behavior and activities of individuals at the research site (Creswell, 2010). The observations in this study that the researchers conducted were by observing systematically how the implementation of the vocational education process in the A/B/C Melati 'Aisyiyah Special School, including teachers strategies and teaching methods, media and resources, valuable equipment, kinds of learning activities conducted in the vocational education system.

b) Interview. The qualitative interview is the communication process between researchers and informants, either directly or by phone (Creswell, 2010). The interview in this study was a question and answer process on informants, consisting of principals, teachers, and foundation managers. The informants were determined by purposive techniques and key respondents that following the research purpose. The main informant is expected to provide primary data on the implementation of vocational education in the ofA/B/C Melati 'Aisyiyah Special School.

c) Documentation. the data collection by inspecting vital records closely related to implementing vocational education in A/B/C Melati 'Aisyiyah Special School, such as school data information boards, activities picture, vocational education syllabus, and so on. In addition, researchers used secondary data from scientific articles on vocational education and the relevant previous study result to support this study.

When the data has been collected, the next step is to perform the data analysis. The data analysis is an effort to select, sort, comprehend, explain and conclude, then establish the decisions on the data discovered from the data collection process (Miles \&Huberman, 1994). The data analysis techniques used in this study is an interactive analysis model, namely qualitative data analysis that conducted interactively and continuously until completion so that the data reaches saturation point (Miles \&Huberman, 1994), with data analysis components consisting of four main things, namely: data collection, condensation, presentation, and conclusion.

The next step is the data validity calibration. Qualitative validity is an effort to check the accuracy of research results by applying certain procedures (Creswell, 2010). This study to tests the data validity done by the triangulation method, furthermore, achieved by extending the observation period, the purpose of having distinct photograph data submitted by the subject and matching the information they previously conveyed (Idrus, 2009).

\section{FINDINGS AND DISCUSSION}

During the observation, researchers inspect the documentation data board showing that the A/B/C Melati 'Aisyiyah Special School and discover that the school was established on May 11, 1994, and has an active license from the Department of Education and Culture. The school vision is to develop and improve students' ability to become skilled individuals independently and religiously and have life skills. While the school mission has are six-item, namely: a) creating special students who believe, have faith, and noble character; b) provide learning opportunities to children with special needs; c) help special children to overcome the specificity problem; d) supplying special students with science, technology, and art; e) giving special students with work skills, and f) encourage creativity and independence of students.

Based on the interview result with the board of foundations (informant-1), researchers obtained information about the establishment background of this special School. The emergence concerns of 
the 'Aisyiyah North Sumatra Region management to the neglected children and special children whose basic needs and nurture are not met by the parents. As a form of concern and efforts to assist the government in overcoming the problem, the 'Aisyiah Regional Leader of North Sumatra, in this case, driven by the Social Welfare Assembly, establish the Child Social Welfare Institute Melati 'Aisyiyah, which manages orphanages, inclusion schools, and A / B / C special school, as protection and care alternatives facility, for the fulfillment of basic children right, family and the environment strengthening, as well as handling child problems in prevention and handling of neglected children.

This study focused on the implementing process on vocational education system conducted by the A/B/C Melati 'Aisyiyah Special School, Tembung, North Sumatra. The researchers studied four aspects: teacher potential, student potential, supporting facilities, infrastructure, and the learning system and school policies. The discovery of the research found based on descriptiveanalysis review as follows:

\section{Teacher Potential}

Based on the data found in the field, it is known that the A /B/C Melati 'Aisyiyah Special School has 21 teachers, consisting of classroom teachers, lesson teachers, and vocational skills teachers. Then there are also 2 therapists and 3 educational personnel. As explained by informant-2, as follow:

"Teachers in this school consists of fourteen class teachers, and there is one religion teachers, Physical Education teacher (physical education and health) also one person, and for vocational teachers, we have five teachers, each in sewing skills, catering, craft, then music and painting teacher. So there are all 21 teachers, then also with 2 therapists. For education personnel, there are principals, administration, and librarians ..."

Based on data and observations, it appears that Melati'Aisyiyah A/B/C Special School has 17 study groups, whose study times were divided into two sessions, in the morning and afternoon. Based on the data, it is known that three teachers handle two classes. They teach in morning sessions and afternoon sessions, considering the classroom teachers available are only 14 people. The class teacher works from 08.00 am to $02.30 \mathrm{pm}$. Meanwhile, the vocational teachers who provide skills learning work from $03.00 \mathrm{p}$, to $04.00 \mathrm{pm}$. Vocational education is explicitly given to high school students (adults) who have been considered ready to enter the world of work. The skills that were taught were sewing skills, catering, craft, music, and painting. Teachers also prepare students to have confidence in participating in competitions that the government routinely holds. The learning methods used by teachers are generally direct learning, direct instruction, demonstration, and practice, as Informant-3 explains:

"special children education becomes our shared responsibility between the government, educational institutions, parents, community, and related stakeholders. Educating special children must be genuine, sincere, and patient based on gratitude that God will surely give the best grace. The common learning methods conducted were direct learning, direct instruction, demonstration, and practice ..."

Then informant-2 give an explanation related to mentoring conducted by vocational teachers, as follow:

"culinary teachers guide the students to produce food and beverage products worth selling and are in demand by the community; moreover, the students are included in the competition held by the government (LKSN). The Tailoring Teachers are taught and guided to master sewing knowledge, both theory and practice so that students can apply such activities in the competition held by the government (LKSN) and in daily life. Similarly, with craft, music, and painting, it's just that for music and painting students are prepared to follow FLS2N..."

Based on the study result related to the potential of teachers above, it can be analyzed that the teachers at the A/ B / C Melati 'Aisyiyah Special School are professional in their field and have had 
enough experience, considering they have served in the school for more than 20 years. Apart from having both theory and practice knowledge, the teacher is also required to have a patient spirit and understand the difficulties and limitations possessed by the special students so that they can teach with the right strategies and learning methods. Teachers should also try to prepare students to archive, be independent, and have created, as proclaimed in the school's mission.

\section{Student Potential}

Based on the data obtained, it was discovered that the A/B/C Melati 'Aisyiyah Special School has 140 students. With a segregation system, for SLB-A for blind students 18 students, SLB-B for deaf students 59 students and SLB-C for mental problem students about 63 students, including down syndrome children four people. Related to the students potential of informant-3 explained:

"... for the blind students (SLB-A), their school-age is the same as for other normal children, i.e. from 7-12 years old for elementary school level, after which they can continue to junior high school, high school, and even get to college with an inclusive education system. However, for deaf children (SLB-B) and mental problem students (SLB-C, they only have up to high school level, then they have the with work skills and entrepreneurship ..."

Based on observations and interviews, it is known that deaf and mental students can only enroll in elementary school at the age of 9 years, in contrast to visually impaired students. So for grade 1 , they start at the age of 9, but the lessons given are at kindergarten-level lessons. For example, in Islamic Education lessons, they are taught to memorize daily prays readings, on the 4th grade, they are taught the salat practice and recite Iqro' and Al-Qur'an. The basic knowledge given is simply reading, writing, and counting. Generally, they do direct practice in learning and less theory. As the results of the researcher's interview with informant-2 stated:

"... for example, in Islamic lessons, the theory taught only read Iqro' and recite the Qur'an, because another deeper lessons will be hard for them to understand, so we are more on direct practice, importantly they already understand and can pray, they need to understand the basic, when adhan sounds, means it has entered prayer time, then they rushed to perform prayers together ..."

Students at the A/B/C Special School also have outstanding achievements, as the documentation data obtained by researchers, on National Student Skills Competition (LKSN) for Special Children at the Provincial level, organized by the Special Education Working Group, Education Service of North Sumatra Province, on September 27-29, 2018 at SLB-E School at Karya Ujung street, Medan. Two students of Melati special School, namely Syufi Ananta, who is in grade VII student of Melati 'Aisyiyah special school, got second place in the culinary competition by baking SpongeBob tarts shown in figure 1. And then, Ami Pulungan, who is also in grade VII student of Melati 'Aisyiyah particular school, got third place in the sewing competition, and the result is shown in figure 2. In the competition, the participants immediately demonstrate their skills within the given time by the jury, around 8-10 hours. In that time, the participants had to complete the crafting results of their skills perfectly. Meanwhile, students are prepared to participate in the National Student Art Festival and Competition (FLS2N). The image documentation that researchers obtained: 


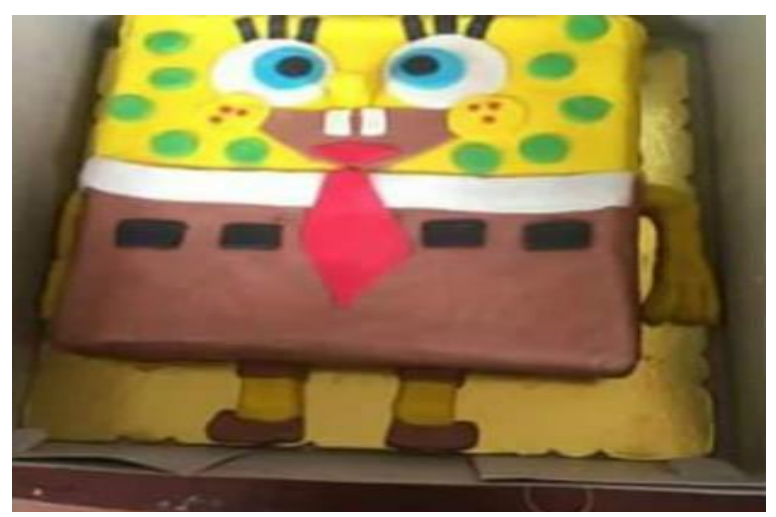

Figure 1. Student's Work Spongebob Tarts

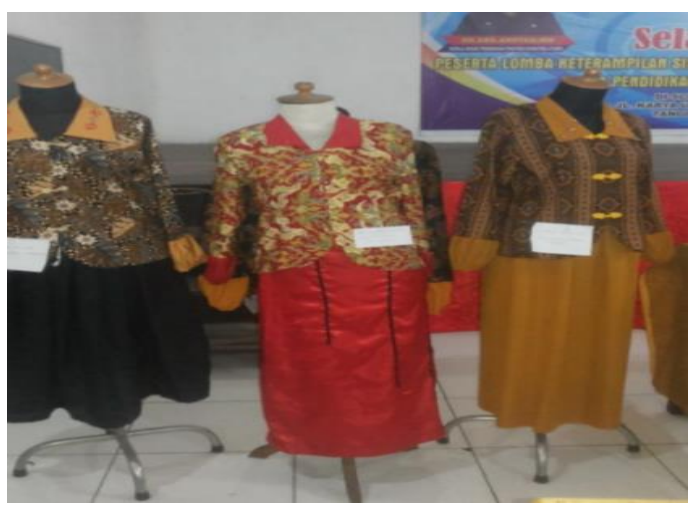

Figure 2. Student Sewing Works

The A/B/C Melati 'Aisyiyah Special School conducts professional management. It has a synergy relationship between potential teachers, established systems, supporting facilities, and exploring students' potential. Thus the students with special needs who initially did not obtain attention can be proud children, achievers, and have independence and responsibility towards themself, so they no longer depend on others.

\section{Facilities and Training Support}

Researchers observed that ABC Melati 'Aisyiyah Special School has adequate infrastructure, such as a large yard, a building consist of 10 classrooms, one office space, one library room (figure 4), and two sanitation rooms. The classroom is ideal for five students, but a class accommodates up to 8 students due to local limitations, as seen in figure 3 . The back of the class is also provided with a place for students to practice culinary skills and shelves to store cooking utensils.

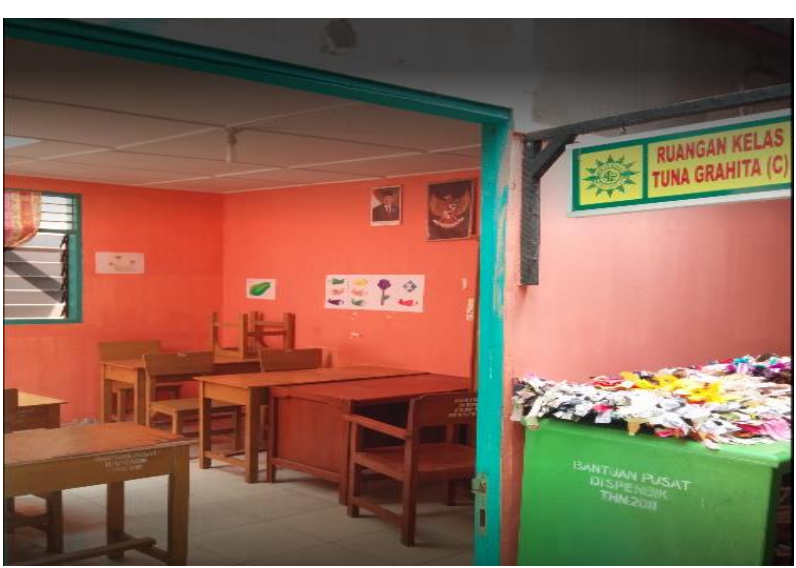

Figure 3. Classroom

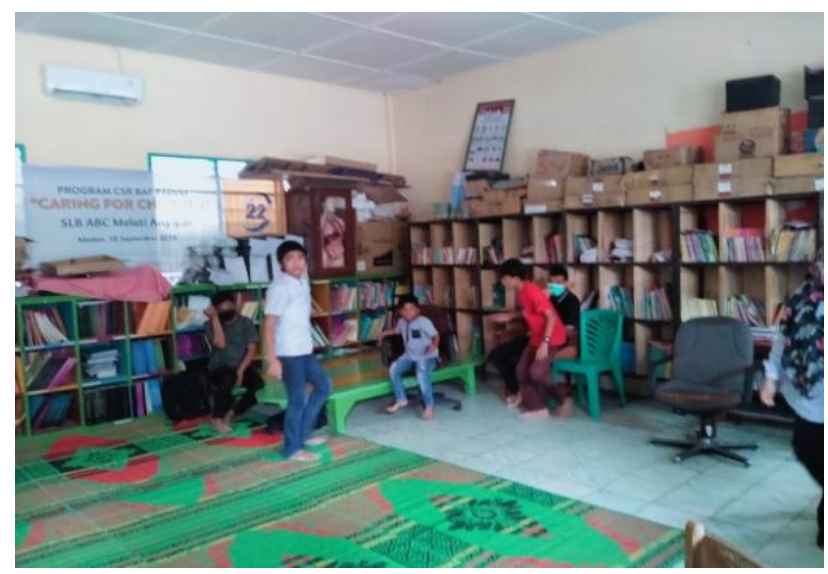

Figure 4. Library Room

As explained by informant-2, namely:

“... means to support vocational skills, such as sewing equipment we have 4 sewing machines, small and wide edge sewing machines, as well as border machines. We also provide cooking practices, such as gas stoves, blenders, mixers, choppers, and stove ovens for baking practices. For music art equipment there are percussion music equipment such as jimbe, tambourine, rebana, timbales, maracas, and there are also keyboards and angklung. For painting equipment, it's consumables such as canvas, brush, watercolor, oil paint, and others. While equipment for skills kriya available carved saws, ordinary saws, hammers, and other consumables ... "

The school has made every effort to meet the needs of students' facilities and infrastructures, such as the availability of study rooms, library rooms, and skill practice rooms. These are equipped with instruments that support vocational learning, such as sewing equipment, cooking, craft, musical 
instruments, and the availability of consumables for painting skills. These facilities and infrastructure are certainly beneficial for students and very helpful for teachers in the learning process, which is more practice by using demonstration methods, training, and learning directly, given the limited conditions that students have. These facilities and infrastructures strongly support vocational education programs launched by the school, with the hope that the students who have work skills and life skills can be independent and ready to enter the world of work in the community.

\section{Learning System}

The academic learning system given to students of the A/B/C Melati 'Aisyiyah Special School is less different from the lessons in public schools. What distinguishes is that there are special lessons given according to the type of willingness. For example, deaf children are given additional lessons on tone and sound perception, while children with mental problem are given additional self-reliance lessons. As informant-4 revealed:

“... for visually impaired students (SLB-A), there are not too many obstacles because they are not bothered by intelligence or social-emotional problems. The only limitations they have are in visual. Different handling with deaf students (SLB-B) needs more guidance, especially in additional lessons such as tone and sound perception, and mental students (SLB-C) who need self-reliance lessons. In this case, we are assisted by therapists to improve their development. ..."

The A/B/C Melati 'Aisyiyah Special school launched the MPLS program or School Environment Introduction Period at the beginning of each school year, as an effort to introduce the school environment for new students and promote the success of students who have been educated at the school through the art performance. Informant-2 explains;

"... at the beginning of the admission year, we carry out the MPLS activities, with the hope that students can be comfortable in school and able to learn well. The first lesson taught is good eating etiquette, which begins with washing hands and recites prayers, they also taught good bathing procedures, then students are introduced to the facilities and the school environment. At the event, the students who have been educated are allowed to display their ability to dance through the student's creative arts performances..."

There are five types of work skills taught for students with special needs. They are sewing, cooking, craft, music, art, and painting. He explained that:

“... in the learning process, students are allowed to develop painting talent, graphic design, culinary, music art, sewing, craft, and entrepreneurship, students also have integrated therapy and speech therapy periodically. There are two school time sessions, which are in the morning, from 08.00 am to 11.00 am, with one break that is 09.30 am -10.00 am. then continued with the afternoon session until 11.30 am to $02.30 \mathrm{pm}$. Then in the afternoon, we implement a vocational system that is students skills training at the high school level, starting at $03.00 \mathrm{pm}$ to $04.00 \mathrm{pm}$..."

The informant statement above is strengthened by documentation data in the form of lesson schedules and a well-planned learning syllabus, regarding the 2013 curriculum. The school regulates academic and vocational learning systems on a proportional basis. Study time is also tailored to the needs and student's abilities, the available local facilities, and the number of teachers in the school. The expected achievement target is also adjusted to the student's condition. Well-planned learning activities will certainly be very helpful in the learning implementation. 
When the researchers were present at the site, the researchers noticed the students were practicing making cassava chips. The school has provided the necessary materials and tools. Students did the cooking activities from cleaning, cutting, frying, to giving chili to the chips. After that, they were also taught how to determine the selling price and market the food they had processed as shown in figure 5 .

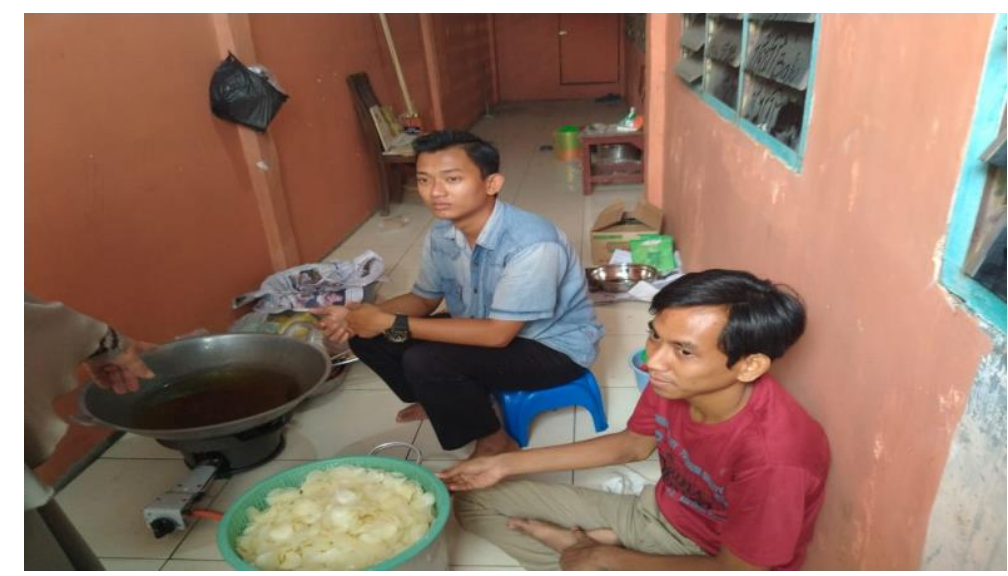

\section{Figure 5. Students with special needs did culinary practice}

The Special School of A/B/C Melati 'Aisyiyah is also open to all parties aimed at helping students progress. They get training from community service programs of lecturers from various universities in North Sumatra. For example, this year, they received training in the manufacture of bath soap from moringa leaves. In addition, in 2019, the school received assistance from PT. Bussan Auto Finance (BAF) which carries the theme "Caring for Children", Corporate Social Responsibility (CSR) program, the assistance provided in the form of providing skills tools, disability aids, school supplies, and so forth.

Based on the observations, interviews, and documentation, it can be analyzed that the learning system in the A/B/C Melati 'Aisyiyah Special School is adjusted to the student's ability level. As though students' ability in the SLB-A class level, the blind students had intelligence that was less different from other normal children, which is distinguishable is only they cannot see. Because of their disability, the way of learning is slightly different. It is different from students in SLB-B and SLB-C. The main lesson given to SLB-B students for deaf children is understanding the perception of sound and tone. As for SLB-C students, namely mental disorder children, the main lesson given is self-reliance. Therefore, it is important to implement a vocational education system that educates them with skills and entrepreneurship until they are ready to enter the world of work and have independence and responsibility for their lives. Therefore, the school took the policy to implement vocational education programs for high school students ready to enter the world of work, equipped with knowledge skills such as sewing, cooking, craft, music, and painting. The school facilitates the availability of exceptional teachers who master the skills, supporting facilities, as well as policies that allocate vocational learning time conducted after academic learning, namely from 03:00 pm to 04:00 pm.

Based on the study results that have been done, it can be analyzed that the $\mathrm{A} / \mathrm{B} / \mathrm{C}$ Melati 'Aisyiyah Special School has been established for 26 years and has a vision, mission, and the purpose of a very noble school. Almost 50\% of students at this school are mental disorder children. The school is well managed and has vocational education programs, supported by professional skills guidance teachers, student potential, supporting facilities and infrastructure, a well-designed curriculum or learning syllabus, as well as a school policy that allocates special time for students to teach skills lessons in the afternoon. So, the students capable of archive academic education also obtain vocational education. The school also provides opportunities and is open to various parties who want to provide material assistance and training to advance the school and improve students' skills. 
The policy that supports vocational education in The Melati 'Aisyiyah A/B/C Special School, the availability of special time for training or skills lessons, is the policy of providing opportunities for students to work outside the school, the purpose of the school is to provide opportunities for students to gain experience learning through work directly and to make students more independent and realize the responsibilities in the world of work. The Determination of such work permits are 4 days of school and 2 days for work, some are 3 days for them to go to school and 3 days they work. If the business owner feels appropriate with their work, the student can continue working in the workplace after graduating high school. For now, the school is cooperating with the durian pancake home industry to accommodate the students who are skilled in culinary, some work in the bird wallet farm and the workshop.

The A/B/C Melati 'Aisyiyah Special School organizes a vocational education system with the vision of developing and improving the student's ability to become skilled, independent, and religious people and have life skills. Those matters are parallel with the opinion of Dasel \&Marcus (2019) that vocational education prepares students to have skills, entrepreneurship, and career skills in certain fields following the special student's maturity. This opinion is reinforced by the results of Breyer et al. (2020). The study states that vocational skills training is given in school, can be qualified in supporting people with disabilities to obtain employment, of course, this also answers the problem raised by Yusof (2014), who discover that the placement of work of people with disabilities is not suitable with the vocational skills that they receive in school. This study seeks to uncover some aspects of supporting the implementation of vocational education in special schools, as follows:

First, the teacher's potential is very important in the vocational education success, this matter is realized by the A/ B / C Melati 'Aisyiyah Special School, so they prepare vocational teachers who are professional in their field. The effort is in line with the results of Akrim \& Rizka's (2019) study, which states that educating special children requires teacher's competency skills, the right strategies, and learning methods. This is reinforced by Harfiani \& Akrim (2020) opinion, which states that problems in educating special children can be solved by the full cooperation and support of parents, teachers, schools, communities, and government.

Second, the potential of students of the Special School can certainly be explored as optimally as possible, so that they can become independent, skilled, and responsible human beings. In line with the opinion of Iswari (2008), who states that vocational skills are the self-potential that contained individuals to be able to live decently and dignifiedly in the community. This opinion is reinforced by the results of Tomblin \& Haring's study (1999), which shows the importance of vocational education for students with special needs in Special schools so that they have independence and skills in the world of work.

Third, the facilities and infrastructures that support the successful implementation of vocational education have been pursued by the A/B/C Melati 'Aisyiyah Special School by providing a variety of instruments for learning sewing, culinary, crafting, music, and painting skills. This effort is in line with the opinion of Ekosiswoyo \& Sutarto (2015) which states that the quality of the vocational learning process is influenced by factors of teachers, infrastructure, financing, leadership, working climate, student's ability, and local support. This is also parallel with the results of Ratnengsih's research (2017), which discover the obstacles that are often found in the implementation of the vocational skills are from the aspect of facilities and infrastructure, in addition to other obstacles learning aspects, human resources, and marketing.

Fourth, the learning system designed and established determine the success of vocational education implementation. This is what makes the A/B/C Melati 'Aisyiyah Special School create the policy of allocating special time for vocational education programs after academic lessons and giving permission for students to gain learning experience by working outside the school. The policy is supported by Law Number 8 of 2016, which states that private companies are obliged to employ $1 \%$ of people with disabilities. According to Prihatin et al. (2018), this is a form of government support 
in providing employment opportunities for people with disabilities. The policy is also in line with Wijaya et al.'s opinion (2018), which states that curriculum implementation for special children at the high school level should prioritize vocational skills, with a ratio of $40 \%$ academic material and $60 \%$ vocational learning. Afriliani (2016) states that vocational learning focused on the theory and practice development that aims to prepare individuals to compete in work according to their talents, interests, and potentials. This opinion is reinforced by the results of Wiratman et al.'s (2018) study that states that vocational education is either of the ways to increase self-reliance. Especially in conducting economic activities for students with special needs. Cendaningrum (2020) states that the main objectives of the particular School which performing vocational programs, one of which can produce graduates who are ready to enter the world of work or the community, so they are expected to be independent and responsible.

\section{CONCLUSION}

The vocational education system implemented by the A/B/C Melati 'Aisyiyah Special School in North Sumatra has potential teachers. The teachers are professionals in their field. The students are potential with a variety of limitations and privileges that the talents and interests need to be explored. Facilities and infrastructure support the implementation of vocational skills learning and a beautifully learning system design and policies taken by schools. Allocating special time for each day in the afternoon for high school students to participate in vocational education programs and permitting them to gain learning experience by working outside schools, so that they are more independent and understand the work responsibilities in the community.

\section{REFERENCES}

Afriliani, L. (2016). Fungsi Bimbingan Keterampilan Vokasional (Vocational Skill) Bagi Penyandang Disabilitas Netra (Studi di Balai Rehabilitasi Sosial Disabilitas Netra "Pendowo" Kudus). Universitas Negeri Semarang.

Ainun, S. N., \& Martias, Z. (2020). Meningkatkan Keterampilan Vokasional Membuat Kue Brownies Melalui Metode Pembelajaran Langsung bagi Anak Tunarungu. Ranah Research: Journal of Multidisciplinary Research and Development, 3(1), 36-40.

Akrim, M., \& Harfiani, R. (2019). Daily learning flow of inclusive education for early childhood. Utopia y Praxis Latinoamericana, 24(Extra6), 132-141.

Amelia, H., \& Armaini. (2020). Efektivitas Metode Demonstrasi dalam Keterampilan Vokasional Membuat Souvenir Boneka dari Kaus Kaki bagi Anak Tunagrahita Ringan. Ranah Research: Journal of Multidisciplinary Research and Development, 3(1), 136-143.

Anisa, A. N. (2020). Penggunaan Media Berbasis Video Untuk Pembelajaran Keterampilan Vokasional Tata Boga Tunagrahita. Jurnal Pendidikan Khusus, 1-7.

Breyer, C., Wilfling, K., Leitenbauer, C., \& Gasteiger-Klicpera, B. (2020). The self-efficacy of learning and support assistants in the Austrian inclusive education context. European Journal of Special Needs Education, 35(4), 451-465. https://doi.org/10.1080/08856257.2019.1706255

Cendaniarum, W. B. (2020). Pengelolaan Layanan Keterampilan Vokasional Siswa Tunarungu. Jurnal Inspirasi Manajemen Pendidikan, 8(3), 167-177.

Creswell, J. W. (2010). Research Design Pendekatan Kualitatif, Kuantitatif dan Mixed. Pustaka Pelajar.

Dasel, J., \& Marcus, E. (2019). Vocational Skills and its Importance to Persons with Special Needs in Nigeria. International Journal of Innovative Science and Research Technology, 4(10), 8-11.

Ekosiswoyo, R., \& Sutarto, J. (2015). Model Pembelajaran Pendidikan Kesetaraan Berbasis Keterampilan Vokasional. Journal of Nonformal Education, 1(1), 35-42. https://doi.org/10.15294/jne.v1i1.3981

Evers, R. B. (1996). The positive force of vocational education: Transition outcomes for youth with learning disabilities. Journal of Learning Disabilities, 29(1), 69-78. https://doi.org/10.1177/002221949602900109

Faroga, A., Mulyasana, D., \& Hanafiah. (2018). Manajemen pembelajaran keterampilan handycraft untuk meningkatkan wirausaha siswa slb. NER SPs Uninus, 1(1), 63-74.

Harfiani, R., \& Akrim, A. (2020). Alternative of troubleshooting inclusive education in kindergarten. $\begin{array}{lllll}\text { Utopia } y & \text { Praxis } & \text { Latinoamericana, 25(Extra 6), 239. }\end{array}$ 
https://doi.org/10.5281/zenodo.3987612

Haryeti, E., Sopandi, A. A., \& Iswari, M. (2013). Meningkatkan Keterampilan Membuat Palai Rinuak Melalui Metode Latihan Pada Anak Tunagrahita Ringan. E-JUPEKhu (JURNAL), 2(3), 537547.

Idrus, M. (2009). Metode Penelitian Ilmu Sosial. Erlangga.

Iswari, M. (2008). Kecakapan Hidup Bagi Anak Berkebutuhan Khusus. UNP Pres.

Jaya, H., Haryoko, S., Saharuddin, Suhaeb, S., Sabran, \& Mantasia. (2018). Life Skills Education for Children with Special Needs in order to Facilitate Vocational Skills. Journal of Physics: Conference Series, 1028(1). https://doi.org/10.1088/1742-6596/1028/1/012078

Lia, N., Syamwil, R., \& Widayani, S. (2017). Model Pembelajaran Keterampilan Vokasional Berbasis Potensi Lokal di SMA Wilayah Kalimantan. Journal of Vocational and Career Education, 2(2), 50-58. https://doi.org/10.15294/jvce.v2i2.13836

Marjuki. (2010). Penyandang Cacat Berdasarkan Klasifikasi ICF. Kepala Badan Penelitian dan Pendidikan Kemensos RI. Kementerian Sosial RI.

Miles, M. ., \& Huberman, A. (1994). Qualitative Data Analysis: A Sourcebook of New Method. CA: Sage.

Mufiddah, R. K., Efendi, M., \& Sulthoni. (2019). Program Vokasional Siswa Tunagrahita di SMALB Malang ( Studi multi situs di Sekolah Menengah Atas Luar Biasa Malang ). Jurnal Ortopedagogia, 5(November), 74-80.

Muspita, R., Safaruddin, S., Ardisal, A., \& Sopandi, A. A. (2018). Pembelajaran Keterampilan Membuat Ikan Bakar Bagi Anak Hambatan Pendengaran. Jurnal Pendidikan Kebutuhan Khusus, 2(2), 48-50. https://doi.org/10.24036/jpkk.v2i2.526

Ningtyas, T. D. D. A. (2020). Penerapan Metode Proyek Dalam Pembelajaran Keterampilan Vokasional Anak Tunagrahita Ringan Di SMALB-C. Jurnal Pendidikan Khusus.

Pratama, A., \& Efendi, J. (2019). Pengaruh Model Direct Instruction dalam Meningkatkan Keterampilan Vokasional Membuat Hiasan Kotak Tisu dari Kain Flanel bagi Anak Tunarungu Kelas VIII SLB Perwari Padang. Jurnal Penelitian Pendidikan Khusus, 7(1), 183-189.

Prayogo, M. M. (2019). Keterampilan Tata Boga Bagi Siswa Autis di SMK Inklusif Kota Bandung. Inklusi, 6(2), 179. https://doi.org/10.14421/ijds.060201

Prihatin, E., Diana, I., \& Permana, J. (2018). Model Manajemen Pendidikan Life Skill pada Anak Berkebutuhan Khusus. Jurnal Penelitian Pendidikan, 18(3), 306-317.

Purwanta, E., \& Hulfa. (2018). Application of e-marketing in entrepreneurship learning for student with intellectual disability. Cakrawala Pendidikan Jurnal Ilmiah Pendidikan, 3(1).

Rahmawati, D. (2019). Pelaksanaan Pembelajaran Keterampilan Vokasional Laundry Anak Tunagrahita di SLB Negeri 1 Yogyakarta. Jurnal Widia Ortodidaktika, 8(10), 1025-1037.

Ratnengsih, E. (2017). Implementasi Program Vokasional Bagi Anak Tunagrahita. JASSI_anakku, 18(1), 77-83.

Riyani, I., Abdurahman, M., \& Tarsidi, I. (2016). Keterampilan Vokasional Pembuatan Telur Asin Bagi Anak Tunagrahita Ringan SMALB di SLB C YPLB Kota Bandung. Jassi Anakku, 17(1), 2633 .

Rizqi, A. N. (2020). Model Pembelajaran Langsung Dalam Meningkatkan Keterampilan Vokasional Mencuci Motor Anak Tunagrahita Ringan. Jurnal Pendidikan Khusus.

Rusdiansyah, F., \& Sujarwanto. (2013). Tracer Study Dunia Kerja Anak Tunagrahita Pasca SMALB Se-Kabupaten Sidoarjo. E-Journal UNESA: Jurnal Pendidikan Khusus, 6(6), 1-7.

Safera, O., \& Hasan, Y. (2019). Meningkatkan Keterampilan Vokasional Menanam Seledri melalui Metode Explicit Instruction pada Anak Tunagrahita Ringan. E-Jupekhu, 7(1), 249-257.

Sani, Y. (2016). Pengembangan Program Keterampilan Vokasional Untuk Meningkatkan Produktifitas Kerja Bagi Anak Tunarungu di SLBN Bekasi Jaya. repository.upi.edu.

Saptaringga, S. (2014). Implementasi Metode Latihan Keterampilan/Drill Pada Pembelajaran Keterampilan Vokasional Otomotif Untuk Siswa Difabel (Tunarungu) Di SMALB”. Penelitian. repository.upi.edu.

Seprinawati dan Jon Efendi. (2019). Pelaksanaan Pembelajaran Keterampilan Vokasional Membuat Sandal Kulit bagi Anak Tunagrahita Ringan di SLB Negeri 2 Padang. Jurnal Penelitian Pendidikan Kebutuhan Khusus, 7(1), 154-159.

Subagja, R. D. (2020). Pembelajaran Keterampilan Vokasional Tata Boga Keripik Kulit Lumpia Pada Anak Tunagrahita Ringan Di SLB Hanjuang Jaya. In Universitas Pendidikan Indonesia. 
repository.upi.edu. https://doi.org/10.1155/2010/706872

Tomblin, M. J., \& Haring, K. A. (1999). Vocational training for students with learning disabilities: A qualitative investigation. Journal of Vocational Education and Training, 51(3), 357-370. https://doi.org/10.1080/13636829900200093

Wijaya, B. (2018). Implementasi Kurikulum Muatan Lokal Vokasional. http://journal2.um.ac.id/index.php/jo/article/view/4979

Wiratman, A., Yuliana, I., \& Roihana. (2018). Learning of Vocational Skill For Empowerment The Spirit of Special Needs of Children. Jurnal Pendidikan Inklusi, 1(1), 21-29.

Yusof, A. M., Ali, M. M., \& Salleh, A. M. (2014). Employability of Vocational School Leavers with Disabilities. Procedia - Social and Behavioral Sciences, 112(Iceepsy 2013), 1064-1069. https://doi.org/10.1016/j.sbspro.2014.01.1270

Yustika, R. (2020). Program Pembelajaran Keterampilan Vokasional Massage Pada Anak Tunanetra di SLB Negeri Citeureup. repository.upi.edu.

Zuliansyah, Muhammad, . \&, \& Hasan, Y. (2018). Pelaksanaan Program Layanan Keterampilan Vokasional Pangkas Rambut Bagi Siswa SMALB Tunarungu di SLB Negeri 2 Tanjungpinang. Jurnal Penelitian Pendidikan Khusus, 6(1), 14-21. 